\title{
DEVELOPMENT OF MOUSE AND RAT ZYGOTES FOLLOWING TRANSFER TO NON-SYNCHRONIZED RAT AND MOUSE OVIDUCTS
}

\author{
G. BEYER* AND G. H. ZEILMAKER \\ Department of Endocrinology, Growth and Reproduction, \\ Rotterdam Medical Faculty, Rotterdam, The Netherlands
}

(Received 5th October 1972)

It has repeatedly been observed that transfer of zygotes, two-cell stages or blastocysts to the oviduct of a recently mated mouse leads to implantation and subsequent pregnancy (Bittner \& Little, 1937; Tarkowski, 1959; Zeilmaker, 1968).

Studies in vitro have shown that the development of the mouse zygote to the blastocyst stage is frequently hampered by a failure to pass the two-cell stage (Whittingham, 1966). For this critical phase in the development, the ampullar region of the mouse oviduct must be present, either in vivo (Whittingham, 1968a; Cross \& Brinster, 1970) or in vitro (Biggers, Gwatkin \& Brinster, 1962; Whittingham, 1968b, c).

The question arises whether the critical contribution of the oviduct is dependent on the hormonal conditions prevailing after oestrus, since Whittingham (1968c) demonstrated, in explantation studies with oviducts containing zygotes, that the cycle stage at which the oviducts were explanted influenced egg development.

The present study is concerned with the early development of mouse and rat zygotes after their transfer to the oviducts of prepuberal, cyclic and pregnant mice and prepuberal rats. Mouse zygotes were collected from Swiss mice between 13.00 and 15.00 hours on the day a vaginal plug was found. The oviduct was flushed with modified Krebs-Ringer solution containing pyruvate (Biggers, Whittingham \& Donahue, 1967). Rat zygotes (Wistar strain) were obtained in a similar way. Recipients were prepuberal (closed vagina), cyclic ( 3 to 4 months old), and pregnant (Day 6 or Day 7) $(\mathrm{C} 3 \mathrm{Hf} \times \mathrm{DBAf}) \mathrm{F}_{1}, \mathrm{C} 3 \mathrm{Hf}$ or Swiss mice, and prepuberal Wistar rats. As there was no difference between the recipient mice, the combined results obtained with these strains are presented. Between 15 and $30 \mathrm{~min}$ after collection, the zygotes were transferred to the left oviduct by means of a mouth-blown pipette (Noyes, Doyle, Gates \& Bentley, 1961) under Nembutal sedation. The zygotes with adhering granulosa cells were transferred with as little additional fluid as possible. Occasionally, a small air bubble was also blown into the tube; however, no harmful effects were seen. Embryos were recovered 72 or $96 \mathrm{hr}$ after their transfer by flushing the oviduct and uterus.

* On temporary leave from the Department of Gynaecology and Obstetrics, University of Leiden. 
In order to ascertain whether mouse and rat morulae which were recovered after $72 \mathrm{hr}$ would develop into blastocysts, a 12- to 24-hr period of incubation in 100- $\mu$ l droplets of pyruvate containing medium (Biggers, Whittingham \& Donahue, 1967) under paraffin oil $\left(5 \% \mathrm{CO}_{2}\right.$ in air) was instituted, following isolation. The observations on zygote development are presented in Table 1 . The results show that synchronization of the oviduct is not a requirement for zygote development and that mouse and rat zygotes can develop in xenogeneic oviducts in vivo.

Some of the recovered morulae were transferred to the uterus of pseudopregnant hosts. Thirteen out of twenty-four mouse morulae and seven out of eleven rat morulae recovered from the oviducts of prepuberal mice, and seven out of eight mouse morulae obtained from rat oviducts developed into living

Table 1. Development of mouse and rat zygotes following transfer to a nonsynchronized mouse or rat oviduct

\begin{tabular}{|c|c|c|c|}
\hline Donor & No. and status of recipients & $\begin{array}{c}\text { No. of zygotes } \\
\text { transferred }\end{array}$ & $\begin{array}{l}\text { No. of morulae* recovered/total } \\
\text { no. of embryos recovered }\end{array}$ \\
\hline Swiss mice & $\begin{array}{l}8 \text { prepuberal mice } \\
3 \text { oestrous mice } \\
9 \text { metoestrous mice } \\
5 \text { dioestrous mice } \\
5 \text { pro-oestrous mice } \\
3 \text { pregnant mice, Day 6/Day } 7 \\
6 \text { prepuberal rats }\end{array}$ & $\begin{array}{l}36 \\
22 \\
82 \\
36 \\
25 \\
25 \\
46\end{array}$ & $\begin{array}{l}17 / 24 \\
20 / 20 \\
45 / 54 \\
11 / 12 \\
18 / 18 \\
18 / 24 \dagger \\
17 / 24\end{array}$ \\
\hline Rats & 19 prepuberal mice & 127 & $47 / 106 \ddagger$ \\
\hline
\end{tabular}

* Following a 12- to 24-hr period in vitro, thirty-four out of thirty-eight mouse morulae and thirteen out of seventeen rat morulae developed into blastocysts.

$\dagger$ Six of these eighteen embryos, recovered after 90 to $96 \mathrm{hr}$, were found to be in the blastocyst stage.

$\ddagger$ Ten of these forty-seven embryos, recovered after 90 to $96 \mathrm{hr}$, were found to be in the blastocyst stage.

young. This indicates that the developmental potential of the eggs is normal. The number of degenerated and lost eggs is not indicated, but empty zonae and degenerated eggs were encountered in all groups. Apart from one morula obtained from the uterus of a recipient mouse, all rat and mouse morulae and blastocysts which developed in the oviduct of the prepuberal mice were recovered from the oviduct. It seems, therefore, that egg development proceeded without normal egg transport.

These observations may be of practical importance when further development of rat and mouse zygotes is required and synchronized recipients are not available. A similar independence from the endocrine status of the host was noticed by Brinster \& Thomson TenBroeck (1969) and by Lawson, Adams \& Rowson (1972) in a study on the development of mouse eggs (two-cell stage) and sheep eggs (two- to twenty-six-cell stage) in the oviduct of the rabbit.

\section{REFERENCES}

Biggers, J., Gwatkin, R. B. L. \& Brinster, R. L. (1962) Development of mouse embryos in organ cultures of Fallopian tubes on a chemically defined medium. Nature, Lond. 194, 747. 
Biggers, J. D., Whittingham, D. G. \& Donahue, R. P. (1967) The pattern of energy metabolism in the mouse oocyte and zygote. Proc. natn. Acad. Sci. U.S.A. 58, 560.

Bittner, J. J. \& Little, G. G. (1937) Transmission of breast and lung cancer in mice. F. Hered. $28,117$.

Brinster, R. L. \& Thomson TENBroeck, J. (1969) Blastocyst development of mouse pre-implantation embryos in the rabbit Fallopian tube. 7. Reprod. Fert. 19, 417.

Cross, P. G. \& Brinster R. L. (1970) In vitro development of mouse oocytes. Biol. Reprod. 3, 298.

Lawson R. A. S., Adams, C. E. \& Rowson, L. E. A. (1972) The development of sheep eggs in the rabbit oviduct and their viability after re-transfer to ewes. $\mathcal{F}$. Reprod. Fert. 29, 105.

Noyes, R. W., Doyle, L. L., Gates, A. H. \& Bentley, D. L. (1961) Ovular maturation and fetal development. Fert. Steril. 12, 405.

TARKowski, A. (1959) Experiments on the transplantation of ova in mice. Acta theriol. 2, 251.

Whittingham, D. G. (1966) A critical phase in the cultivation of mouse ova in vitro. 7. Cell Biol. 31, $123 \mathrm{~A}$.

Whittingham, D. G. (1968a) Fertilization of mouse eggs in vitro. Nature, Lond. 220, 592.

Whittingham, D. G. (1968b) Development of zygotes in cultured mouse oviducts. I. Effect of varying oviductal conditions. F. exp. Zool. 169, 391 .

Whittingham, D. G. (1968c) Development of zygotes in cultured mouse oviducts. II. The influence of the estrous cycle and ovarian hormones upon the development of the zygote. F. exp. Zool. 169, 399.

ZeilmakeR, G. H. (1968) Transmission of mammary tumor virus by female GR mice: results of egg transplantation. Int. Fnl Cancer, 4, 261. 